\title{
The hemostatic profile of recombinant activated factor VII. Can low concentrations stop bleeding in off-label indications?
}

\author{
Raul Altman*1, Alejandra Scazziota' ${ }^{1}$, Maria de Lourdes Herrera ${ }^{1}$ and Claudio D Gonzalez²
}

\begin{abstract}
Background: High concentrations of recombinant activated factor VII ( $\mathrm{rFVIla)}$ can stop bleeding in hemophilic patients. However the rFVlla dose needed for stopping haemhorrage in off-label indications is unknown. Since thrombin is the main hemostatic agent, this study investigated the effect of rFVlla and tissue factor (TF) on thrombin generation (TG) in vitro.

Methods: Lag time (LT), time to peak (TTP), peak TG (PTG), and area under the curve after 35 min (AUCo-35 min) with the calibrated automated thrombography was used to evaluate TG. TG was assayed in platelet-rich plasma (PRP) samples from 29 healthy volunteers under basal conditions and after platelet stimulation with $5.0 \mu \mathrm{g} / \mathrm{ml}, 2.6 \mu \mathrm{g} / \mathrm{ml}, 0.5$ $\mu \mathrm{g} / \mathrm{ml}, 0.25 \mu \mathrm{g} / \mathrm{ml}$, and $0.125 \mu \mathrm{g} / \mathrm{ml} \mathrm{rFVlla} \mathrm{alone} \mathrm{and} \mathrm{in} \mathrm{normal} \mathrm{platelet-poor} \mathrm{plasma} \mathrm{(PPP)} \mathrm{samples} \mathrm{from} 22$ healthy volunteers, rFVIla in combination with various concentrations of TF (5.0, 2.5, 1.25 and 0.5 pM).

Results:

In PRP activated by rFVIla, there was a statistically significant increase in TG compared to basal values. A significant TF dose-dependent shortening of LT and increased PTG and AUCoT 35 min were obtained in PPP. The addition of rFVIla increased the effect of TF in shorting the LT and increasing the AUCoT 35 min with no effect on PTG but were independent of $\mathrm{rFVlla}$ concentration.

\section{Conclusion:}

Low concentrations of rFVIla were sufficient to form enough thrombin in normal PRP or in PPP when combined with $\mathrm{TF}$, and suggest low concentrations for normalizing hemostasis in off-label indications.
\end{abstract}

\section{Introduction}

In severe bleeding it is vital to achieve normal hemostasis. Replacement therapy with active plasma derivatives can help to stop hemorrhaging, but treatment with plasma or plasma-derived concentrates also carries the risk of blood-borne virus transmission and volume overload. In recent years, treatments with recombinant activated factor VII (rFVIIa) has been proposed for hemophilic patients with inhibitors, and in off-label use for different bleeding conditions [1,2]. The optimal dose of rFVIIa in off-label indications needed to manage

* Correspondence: draltman@arnet.com.ar

${ }^{1}$ Centro de Trombosis de Buenos Aires, Viamonte 2008, 1056 Buenos Aires, Argentina

Full list of author information is available at the end of the article patients with severe uncontrolled bleeding is unknown, and there is an estimated $1.4 \%$ incidence of thromboembolism in patients treated with rFVIIa for conditions other than hemophilia [3]. Low-dose rFVIIa produced satisfactory results in cardiac patients with intractable bleeding [4] and in trauma patients with coagulopathy [5]. In this context, notwithstanding the presence of underlying medical conditions, hemostasis could be related to the concentrations of rFVIIa in the blood after its infusion. However, high concentrations of rFVIIa combined with tissue factor (TF) released after atheroma inflammation, injury, or rupture could increase the thrombin forming capacity in situ. In this situation, the question is whether this constitutes a potential prothrombogenic condition. 
In this study, the thrombin generation (TG) capacity of different concentrations of rFVIIa was assayed in plateletrich plasma (PRP) from healthy volunteers, and in platelet-poor plasma (PPP) combined with "theoretically" high and low TF concentrations to determine the minimal amount of rFVIIa needed to produce maximal TG. In vitro, we found that the amount of TG is greatly dependent on TF and rFVIIa concentration when these are used alone, but is independent of rFVIIa concentration when combined with TF. These results could have important clinical implications for using low doses of rFVIIa.

\section{Materials and methods \\ Subjects}

Twenty-nine healthy volunteers (18 women and 11 men) with no history of thromboembolic or hemorrhagic diseases, cardiac, renal, hepatic, or malignant diseases, were required to be drug free for 10 days before the study. Informed consent was obtained from all volunteers before participating in the study. Only subjects with a normal platelet count, prothrombin time, and activated partial thromboplastin time that fulfilled the inclusion criteria were used for the TG assay with rFVIIa. Twenty two PPP samples from the same normal volunteers (13 women and 9 men) were used to test TF or TF plus rFVIIa in TG assays. The protocol was approved by the institutional review board.

\section{Methods}

The methodology was similar to that previously described [6]. Fluorogenic thrombin substrate (Z-GlyGly-Arg-AMC; Bachem, Switzerland) was dissolved in dimethylsulfoxide (DMSO) at a concentration of 100 $\mathrm{mM}$. A stock solution was prepared containing $100 \mathrm{mM}$ fluorogenic substrate, $1 \mathrm{M} \mathrm{CaCl}_{2}$ and Fluo Buffer (20 mmol/l HEPES, pH 7.35, containing $60 \mathrm{mg} / \mathrm{ml}$ bovine serum albumin (Sigma, St. Louis, MO, USA). For the TG assays, a working solution containing $2.5 \mathrm{mM}$ fluorogenic substrate, $100 \mathrm{mM} \mathrm{CaCl}$, and 2.5\% (v/v) DMSO were used. rFVIIa was Novo Seven, from NovoNordik, Bagsvćrd, Denmark. Tissue factor containing 5 pM TF and $4 \mu \mathrm{M}$ phospholipids was supplied by Synapse BV (Maastricht, The Netherlands; PPReagent cat. no. TF 30.00).

\section{Thrombin generation study}

Venous blood was withdrawn from the antecubital vein without stasis and mixed with $0.11 \mathrm{M}$ sodium citrate $(1: 10 \mathrm{v} / \mathrm{v})$. The PRP was obtained by centrifugation at 150 $\times g$ for $10 \mathrm{~min}$ at room temperature, and PPP was obtained by centrifuging the PRP at $900 \times g$ for $15 \mathrm{~min}$. The PRP was adjusted to a platelet count of 290,000-
$310,000 / \mu$ l with autologous PPP. If contamination of PRP with erythrocytes or leukocytes was observed by light microscopy, a second centrifugation at $900 \times g$ for $5 \mathrm{~min}$ was carried out to minimize the number of these cells. Plastic syringes, tubes, and pipettes were used for all tests. To prevent the inclusion of normal volunteers who may have taken any drug capable of affecting platelet function, platelet aggregation in the PRP was measured photometrically in a double-channel Lumi-Aggregometer (Chrono-log Corp., Havertown, PA, USA). Light transmittance was set at $10 \%$ for PRP and $90 \%$ for PPP. The aggregating agent (1-10 $\mu \mathrm{l})$ was added to the PRP in the aggregometer at $37^{\circ} \mathrm{C}$ with constant stirring (1000 rpm); AA $0.75 \mathrm{mM}$ and ADP $2 \mu \mathrm{M}$ were used as platelet-aggregating agents. If samples from normal volunteers showed abnormal platelet aggregation in response to AA or ADP, they were discarded and the results were excluded from the study. Platelet activation is a very sensitive process and activation during blood withdrawal or PRP preparation could affect the final results. To prevent this bias, if the lag time (LT) in PRP samples was less than 1 standard deviation below the average, it was considered activated and was discarded.

TG was measured using the calibrated automated thrombography (CAT) method [7] and assayed using an intrinsic coagulation system in which platelets in the PRP were activated with rFVIIa. TG was also measured in PPP by adding TF or TF plus rFVIIa. Samples were assayed in round-bottom polypropylene microtiter plates (Greiner Labortechnik, Germany) using a microtiter plate fluorimeter (Fluoroskan Ascent reader, Thermo Labsystems Helsinki, Finland). Tests were performed a mean of $62 \pm 15$ min after blood collection. In PRP, the assay system consisted of $80 \mu \mathrm{l}$ of PRP and $20 \mu \mathrm{l}$ of rFVIIa solution to obtain final concentrations of $5.0 \mu \mathrm{g} / \mathrm{mL}, 2.6 \mu \mathrm{g} / \mathrm{mL}, 0.5$ $\mu \mathrm{g} / \mathrm{mL}, 0.25 \mu \mathrm{g} / \mathrm{mL}$, and $0.125 \mu \mathrm{g} / \mathrm{mL}$ for rFVIIa. In PPP, the assay system was $80 \mu \mathrm{L}$ of PPP and final TF concentrations of $5.0 \mathrm{pM}, 2.5 \mathrm{pM}, 1.25 \mathrm{pM}$, or $0.5 \mathrm{pM}$ alone, or combined with $5.0 \mu \mathrm{g} / \mathrm{mL}, 2.6 \mu \mathrm{g} / \mathrm{mL}$, or $0.5 \mu \mathrm{g} / \mathrm{mL}$ rFVIIa. Registration was initiated at the same time as the fluorogenic working solution was automatically added. Fluorescence was measured at 15-s intervals over a period of $50 \mathrm{~min}$. Each sample was assayed simultaneously in four replicates.

The rFVIIa concentrations of $5.0 \mu \mathrm{g} / \mathrm{mL}, 2.6 \mu \mathrm{g} / \mathrm{mL}$, and $0.5 \mu \mathrm{g} / \mathrm{mL}$ used in both systems are comparable with the predicted concentrations of rFVIIa achieved in plasma by intravenous administration of approximately $200 \mu \mathrm{g} / \mathrm{kg}, 104 \mu \mathrm{g} / \mathrm{kg}$, and $20 \mu \mathrm{g} / \mathrm{kg}$ in vivo, respectively. The lower rFVIIa concentrations of $0.25 \mu \mathrm{g} / \mathrm{mL}$ and 0.125 $\mu \mathrm{g} / \mathrm{mL}$ were used to establish the plateau of the rFVIIa activated assay. 


\section{Definitions}

The LT is the time (in minutes) from the start of the assay to the initial generation of thrombin (the moment that 10 $\mathrm{nM}$ thrombin is formed).

Time to peak TG (TTP) is the time (in minutes) required to reach maximum $\mathrm{TG}$.

Peak TG (PTG) is the maximum thrombin concentration (nM).

Endogenous thrombin potential (ETP) is the area under the curve (AUC) (nM thrombin). ETP was calculated and corrected for $\alpha_{2}$ macroglobulin-thrombin complex activity using Thrombinoscope (Maastricht, Netherlands) software. To ensure comparability of results, the AUC was calculated assuming that the start of the tail occurred at $35 \mathrm{~min}\left(\mathrm{AUCoT}_{35 \mathrm{~min}}\right)$.

\section{Statistical analysis}

Quantitative variables are expressed as the mean \pm standard deviation. The nature of the quantitative variable distribution was explored through the Shapiro-Wilk's test. Differences among groups of quantitative data were tested using one-way analysis of variance (ANOVA). Scheffé post hoc test was applied for multiple betweengroup comparisons. In case of non normally distributed data, Kruskal-Wallis tests (KW) were also performed (Student-Newman-Keuls post hoc). A log transformation of the quantitative data was also carried out, and tested through one way ANOVA (LogANOVA). Significance from these tests (KW and LogANOVA) are computed only when relevant differences with regards to the one way ANOVA obtained from the raw data were found. A p values below 0.05 was considered significant. The software, CSS/Statistica (Software: Statistica v9, 2010, Tulsa, OK, US.) was used for the analyses.

\section{Results}

\section{Effects of rFVlla on TG parameters in PRP}

When normal PRP was activated with different concentrations of rFVIIa, results obtained with all concentrations used were statistically different from saline-treated PRP. When rFVIIa $5.0 \mu \mathrm{g} / \mathrm{mL}$ was compared with the other rFVIIa concentrations $(2.6 \mu \mathrm{g} / \mathrm{mL}, 0.5 \mu \mathrm{g} / \mathrm{mL}, 0.25$ $\mu \mathrm{g} / \mathrm{mL}$, and $0.125 \mu \mathrm{g} / \mathrm{mL}$ ) the LTs were progressively longer (Fig. 1) indicating a dose-dependent rFVIIa activity, although the difference between the lowest concentrations $(0.5 \mu \mathrm{g} / \mathrm{mL}, 0.25 \mu \mathrm{g} / \mathrm{mL}$, and $0.125 \mu \mathrm{g} / \mathrm{mL})$ was not statistically significant. An unexpected tendency (some statistically significant) to increase PTG at the lower rFVIIa concentrations was observed. PTG was statistically lower (Fig 2) when rFVIIa $5.0 \mu \mathrm{g} / \mathrm{mL}$ was compared with $0.5 \mu \mathrm{g} / \mathrm{mL}$, but the other concentrations $(0.25 \mu \mathrm{g} / \mathrm{mL}$ and $0.125 \mu \mathrm{g} / \mathrm{mL}$ ) were not sensitive to rFVIIa dose variations. Based on these results, we decided to use only the higher concentrations of rFVIIa in subsequent experiments.

\section{Effects of TF and rFVIla on TG parameters}

The PPP was used in this set of experiments. The amount of TF released after injury to a blood vessel wall is unknown. We arbitrarily used rTF concentrations of 5.0 $\mathrm{pM}, 2.5 \mathrm{pM}, 1.25 \mathrm{pM}$, and $0.5 \mathrm{pM}$. Increased concentrations of TF dose-dependently shortened the LT and increased PTG and $\mathrm{AUCoT}_{35}$ min levels (Table 1); these changes were statistically significant.

The addition of rFVIIa increased the effect of TF on the $\mathrm{LT}$ and $\mathrm{AUCoT}_{35 \mathrm{~min}}$, but not the PTG. Moreover, differences between different concentrations of rFVIIa were not observed (Table 1).

\section{Discussion}

The relationship between rFVIIa concentration and TG when rFVIIa is used in combination with TF is unknown. In this study, we wanted to establish the correlation between different amounts of rFVIIa in combination with TF on TG when added to normal PRP or PPP in vitro.

The rFVIIa concentrations used in these in vitro experiments are comparable with the predicted concentrations of rFVIIa achieved in plasma by the administration of high (approximately $200 \mu \mathrm{g} / \mathrm{kg}$ ), moderate $(104 \mu \mathrm{g} / \mathrm{kg}$ ), or low $(20 \mu \mathrm{g} / \mathrm{kg})$ doses. Results obtained with rFVIIa concentrations of $5 \mu \mathrm{g} / \mathrm{mL}, 2.6 \mu \mathrm{g} / \mathrm{mL}, 0.5 \mu \mathrm{g} / \mathrm{mL}, 0.125 \mu \mathrm{g} /$ $\mathrm{mL}$, and $0.25 \mu \mathrm{g} / \mathrm{mL}$ were significantly different compared with saline $(\mathrm{p}<0.001)$ for all TG parameters (Fig. 1, 2). Comparing the effect of different doses of rFVIIa, the LT were statistically longer with decreasing doses when rFVIIa $5.0 \mu \mathrm{g} / \mathrm{ml}$ was compared with the other concentrations. Nevertheless, there was no difference among the lowest rFVIIa concentrations $(0.5 \mu \mathrm{g} / \mathrm{mL}, 0.25 \mu \mathrm{g} / \mathrm{mL}$, and $0.125 \mu \mathrm{g} / \mathrm{mL}$ ) (Fig 1). Unexpectedly, the PTG was statistically lower when rFVIIa $5.0 \mu \mathrm{g} / \mathrm{ml}$ was compared with $0.5 \mu \mathrm{g} / \mathrm{ml}$. The other concentrations were similar and independent of the rFVIIa concentration (Figure 2). Thus, only the highest concentrations of rFVIIa $(5.0 \mu \mathrm{g} /$ $\mathrm{mL}, 2.5 \mu \mathrm{g} / \mathrm{mL}$, and $0.5 \mu \mathrm{g} / \mathrm{mL}$ ) were combined with TF to evaluate the effects on TG parameters.

After injury, there is a combined effect of factor VII and $\mathrm{TF}$ in forming the hemostatic plug. In the vessel wall, $\mathrm{TF}$ is constitutively expressed in subendothelial cells, leading to rapid initiation of coagulation when the vessel is damaged. The amount of TF exposed after injury to the blood vessel wall is unknown, as is the contribution of soluble TF. We arbitrarily used TF concentrations of $5.0 \mathrm{pM}, 2.5$ $\mathrm{pM}, 1.25 \mathrm{pM}$, and $0.5 \mathrm{pM}$. All of these concentrations produced a statistically significant, TF dose-dependent decrease in the LT and an increase in the PTG and AUC $\left(\mathrm{AUCoT}_{35 \mathrm{~min}}\right)(\mathrm{p}<0.001$ for all comparisons). The addi- 


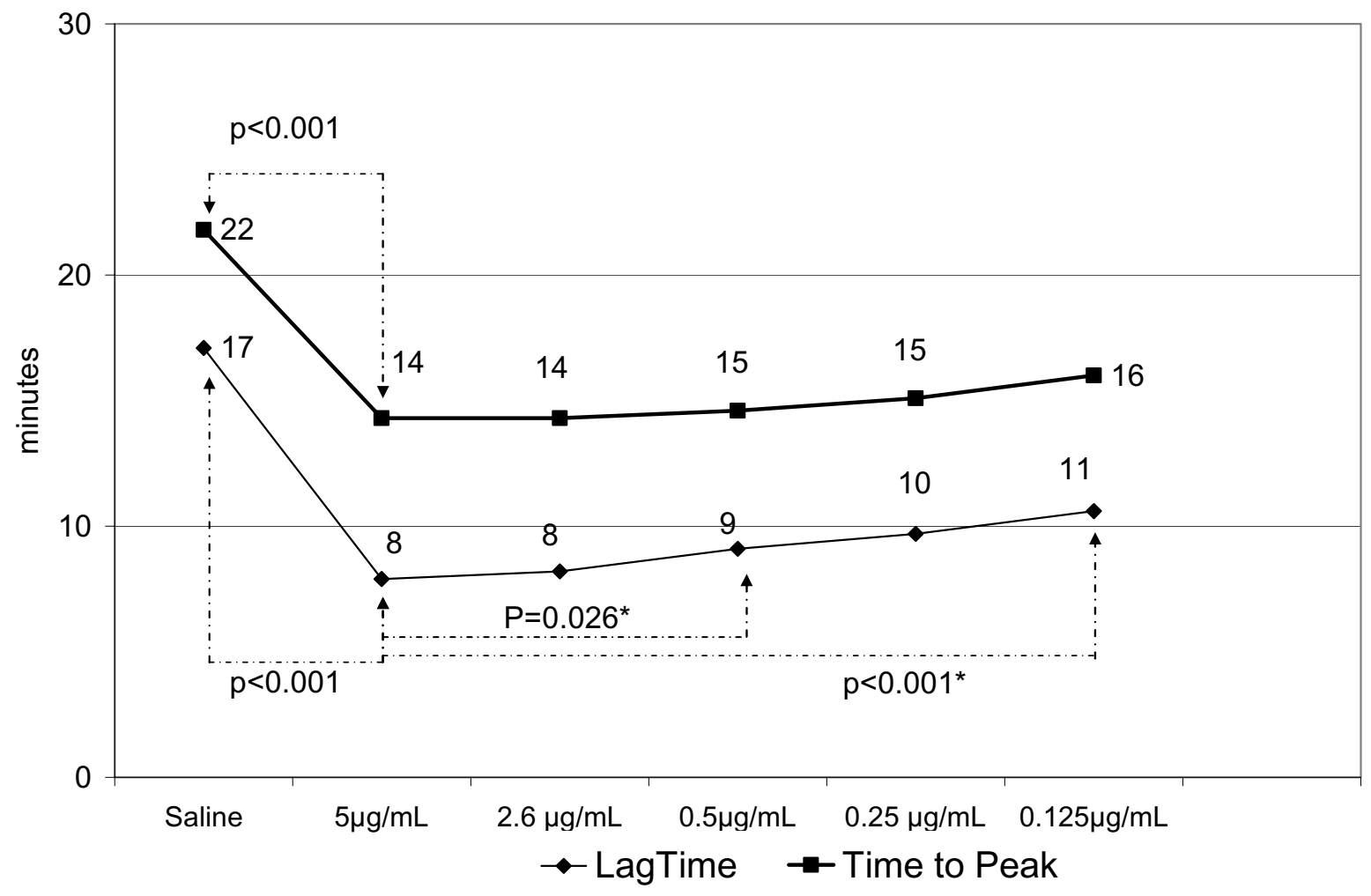

Figure $1 \mathrm{Effect}$ on the lag time and time to peak thrombin generation with different concentrations of recombinant factor $\mathrm{VIla}(5 \mu \mathrm{g} / \mu \mathrm{L}$

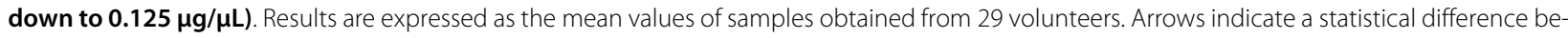
tween values. Saline vs all rFVIla concentrations, $\mathrm{p}<0.001$ (one-way ANOVA). * Differences between different concentrations of rFVIla. Post-hoc comparison.

tion of rFVIIa increased the effect of TF in shorting the LT and increasing the AUCoT 35 min with no effect on PTG (Table 1). These effects are independent of rFVIIa concentration. Indeed, using rFVIIa concentrations of $5 \mu \mathrm{g} /$ $\mathrm{ml}, 2.6 \mu \mathrm{g} / \mathrm{ml}$, or $0.5 \mu \mathrm{g} / \mathrm{ml}$ with fixed concentrations of $\mathrm{TF}$, no differences in TG parameters were observed.

These experiments indicate that rFVIIa, even at low concentrations, in the presence of TF can induce TG in a very short time, an effect that is not dependent on rFVIIa concentration.

In hemophilic patients with inhibitors, rFVIIa is effective in controlling mild to moderate bleeding. Safety data indicate that thromboembolic events are low in these patients. However, when used for off-label indications, rFVIIa-related thrombotic events seem to occur more frequently [8].

The mechanism of action of rFVIIa explains its efficacy in congenital and acquired hemophilia A and B [9-11], and in a range of clinical situations characterized by impaired TG, such as liver disease, platelet disorders, antivitamin $\mathrm{K}$ therapy, antiplatelet therapy [6], and others (excessive bleeding, surgery and trauma, acute intracerebral hemorrhage, cardiovascular surgery) [3,12-14].

The prohemostatic properties of rFVIIa may theoretically have a downside in the form of potential arterial or venous thrombosis associated with its use in adults [1517] and children [18,19] often resulting in mortality and serious morbidity (deep venous thrombosis, myocardial infarction) [20,21].

Added in pharmacological doses, exogenous rFVIIa together with platelet agonists enhances the rate of TG [22] by activating platelet surfaces, increasing the exposure of membrane phospholipids at the site of injury, and initiating local clotting mechanisms [23]. Thrombotic events could be related to local concentrations of thrombin.

Increasing rFVIIa infusions increases the possibility of thrombosis in medical conditions not related to hemophilia with inhibitors [13,14]. A low dose of $1.2 \mathrm{mg}$ of rFVIIa administrated to a study population with traumatic brain injury, warfarin use, and cirrhosis led to a reduction in the mean prothrombin time from $17.0 \pm 3.2$ 


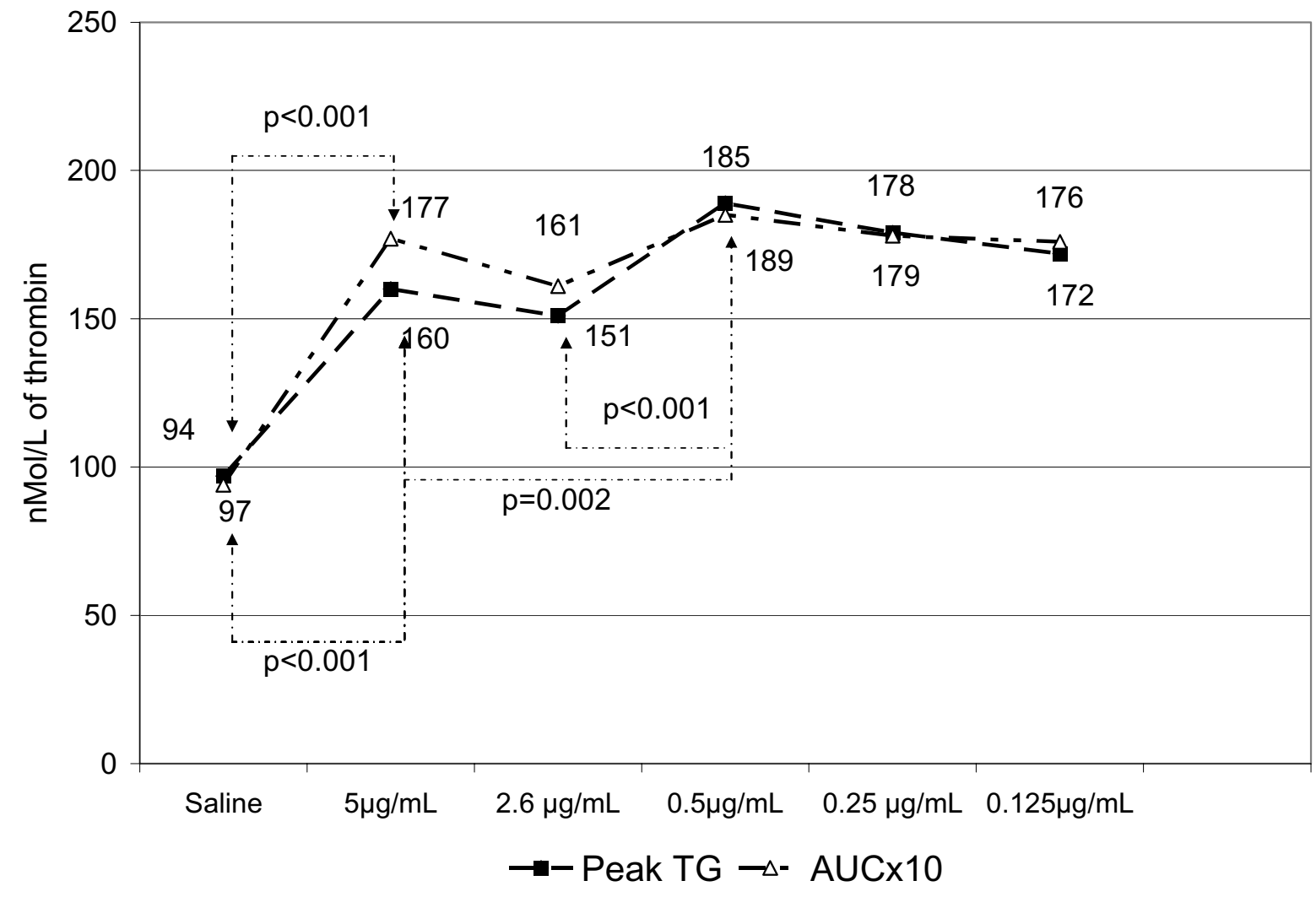

Figure 2 Effect on the amount of thrombin generation (peak thrombin generation or PTG) and area under the curve (AUCx10) of different

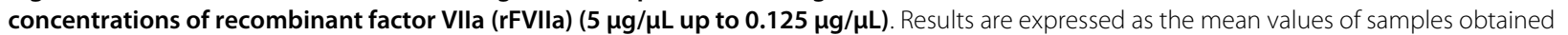
from 29 volunteers. Arrows indicate a statistical difference between values. When saline was compared with all rFVlla concentrations, $p<0.001$ (oneway ANOVA). Differences between different concentrations of rFVIla. Post-hoc comparison.

$\mathrm{s}$ to $10.6 \pm 1.4 \mathrm{~s}(\mathrm{p}<0.0001)$ [5] indicating an important increase in thrombin formation easily detected with this basic clotting test.

Some clinical conditions that are mediated by TF exposure in the circulation may theoretically carry a risk of adverse thrombotic reactions upon administration of rFVIIa. An example of such a condition is patients with semi-ruptured atherosclerotic plaques that are known to contain abundant TF. In this situation, rFVIIa may hypothetically precipitate an acute thrombotic event, such as a myocardial infarction [20,21]. Another condition that is associated with systemic TF release into the circulation is disseminated intravascular coagulation: TF, expressed on the surface of activated mononuclear cells and endothelial cells, activates factor VII [24]. Moreover, in patients with antecedents of myocardial infarction, elevated levels of circulating microparticles originating from platelets, and endothelial cells can be associated with thrombotic disorders [25]. Administration of rFVIIa could theoretically lead to a more severe coagulopathy and aggravate systemic microvascular thrombosis when combined with TF released from monocytes [24,26].

In hemophilia with inhibitors, the dose of rFVIIa used can be as high as $270 \mu \mathrm{g} / \mathrm{kg}$ [27]. Smaller doses showed satisfactory results in some off-label conditions, such as cardiac patients with intractable bleeding [4,28] and trauma patients with coagulopathy [5]. For instance, 1.2 mg effectively treated mild to moderate coagulopathy following injury, $1.2 \mathrm{mg}$ and less than $90 \mu \mathrm{g} / \mathrm{kg}$ were effective for severe bleeding in cardiac surgery with few or no thrombotic events, and $20 \mu \mathrm{g} / \mathrm{kg}$ or $40 \mu \mathrm{g} / \mathrm{kg}$ resulted in a $50 \%$ reduction in blood loss in patients with a pre-existing normal coagulation system undergoing abdominal prostatectomy[29]. In the paper by Diringer et al. [21] there were 49 (27\%) arterial events in the placebo group, and in the rVIIa treated group, there were 47 (26\%) arterial events in the 20 -microg/kg group, and $82(46 \%)$ in the $80 \mathrm{microg} / \mathrm{kg}$ group $(\mathrm{P}=0.04)$.

In conclusion, this data might be helpful in studying the effect of low dose of rTFIIa in bleeding situations where 
Table 1: Activating effect of different concentrations of tissue factor (TF), alone or combined with different concentrations of recombinant activated factor VII (rFVIla), on thrombin generation (TG) parameters in normal platelet-poor plasma (PPP)

\begin{tabular}{|c|c|c|c|c|c|c|}
\hline & $\begin{array}{l}\text { Column B } \\
\text { Saline }\end{array}$ & $\begin{array}{l}\text { Column C. rFVIIa } \\
5.0 \mu \mathrm{g} / \mathrm{mL}\end{array}$ & $\begin{array}{l}\text { Column D. rFVIIla } \\
2.5 \mu \mathrm{g} / \mathrm{mL}\end{array}$ & $\begin{array}{l}\text { Column E. rFVIla } \\
0.5 \mu \mathrm{g} / \mathrm{mL}\end{array}$ & $\begin{array}{l}\text { Column B vs C } \\
\text { vs } D \text { vs } E\end{array}$ & $\begin{array}{l}\text { Column C vs } \\
\text { D/C vs E }\end{array}$ \\
\hline \multicolumn{7}{|l|}{ Lag time (min, mean $\pm S D$ ) } \\
\hline TF $5.0 \mathrm{pM}$ & $3.2 \pm 0.7$ & $2.1 \pm 0.4$ & $2.1 \pm 0.4$ & $2.1 \pm 0.4$ & $<0.001$ & 0.999/0.999 \\
\hline TF $2.5 \mathrm{pM}$ & $4.2 \pm 1.2$ & $2.9 \pm 0.7$ & $3.0 \pm 0.6$ & $3.0 \pm 0.6$ & $<0.001$ & $0.686 / 0.686$ \\
\hline TF $1.25 \mathrm{pM}$ & $6.0 \pm 1.4$ & $3.7 \pm 0.9$ & $3.6 \pm 0.9$ & $4.1 \pm 0.7$ & $<0.001$ & $0.744 / 0.196$ \\
\hline TF $0.5 \mathrm{pM}$ & $8.1 \pm 1.8$ & $5.3 \pm 1.1$ & $5.1 \pm 1.2$ & $5.7 \pm 1.2$ & $<0.001$ & $0.627 / 0.332$ \\
\hline$P$-value (one-way ANOVA) & $<0.001$ & $<0.001$ & $<0.001$ & $<0.001$ & & \\
\hline \multicolumn{7}{|c|}{ Peak of TG $(n m o l / l$, mean \pm SD) } \\
\hline TF $5.0 \mathrm{pM}$ & $389 \pm 105$ & $367 \pm 86$ & $385 \pm 84$ & $400 \pm 75$ & 0.661 & \\
\hline TF $2.5 \mathrm{pM}$ & $278 \pm 105$ & $269 \pm 87$ & $269 \pm 86$ & $290 \pm 79$ & 0.746 & \\
\hline TF $1.25 \mathrm{pM}$ & $178 \pm 97$ & $214 \pm 90$ & $217 \pm 94$ & $214 \pm 75$ & 0.421 & \\
\hline TF $0.5 \mathrm{pM}$ & $123 \pm 91$ & $146 \pm 101$ & $145 \pm 99$ & $169 \pm 99$ & 0.489 & \\
\hline$P$-value (one-way ANOVA) & $<0.001$ & $<0.001$ & $<0.001$ & $<0.001$ & & \\
\hline \multicolumn{7}{|l|}{ AUC (nmol/l, mean \pm SD) } \\
\hline TF $5.0 \mathrm{pM}$ & $2094 \pm 425$ & $2389 \pm 435$ & $2337 \pm 431$ & $2454 \pm 387$ & 0.032 & $0.907 / 0.611$ \\
\hline TF $2.5 \mathrm{pM}$ & $1875 \pm 431$ & $2137 \pm 431$ & $2030 \pm 423$ & $2244 \pm 403$ & 0.033 & $0.499 / 0.405$ \\
\hline TF $1.25 \mathrm{pM}$ & $1427 \pm 466$ & $1944 \pm 477$ & $1824 \pm 456$ & $1904 \pm 437$ & 0.001 & $0.391 / 0.922$ \\
\hline TF $0.5 \mathrm{pM}$ & $1115 \pm 507$ & $1512 \pm 664$ & $1426 \pm 561$ & $1659 \pm 613$ & 0.023 & $0.552 / 0.412$ \\
\hline$P$-value (one-way ANOVA) & $<0.001$ & $<0.001$ & $<0.001$ & $<0.001$ & & \\
\hline
\end{tabular}

ANOVA $=$ analysis of variance

arterial or venous thrombosis can occur despite bleeding. This seems to fit with some clinical obsevations regarding the efficacy of low-dose rFVIIa in stopping bleeding in off-label indications.

For off-label use, no particular dose of factor rVIIa is recommended in the literature, and thromboembolic events may be dose dependent [30]. Using the smallest possible dose is warranted not only because of the expense of factor rVIIa, but because of the potential thromboembolic events [30].

In this context and because rFVIIa may increase the risk of arterial thrombosis [31], we speculate that using excess rFVIIa in off-label indications combined with TF generated in disrupted or inflamed atheromas or other clinical conditions can induce thrombotic events, since the TF-FVIIa complex drives the intrinsic coagulation pathway to form thrombin and fibrin [32].

\section{Competing interests}

The authors declare that they have no competing interests.

\section{Authors' contributions}

RA designed the study and coordination, drafted the manuscript and discussed the results. AS carried out the lab assays and discussed the results. MLH carried out the lab assays and discussed the results. DCG performed the statis- tical analysis and discussed the results and participated in its design. All authors read and approved the final manuscript.

\section{Author Details}

'Centro de Trombosis de Buenos Aires, Viamonte 2008, 1056 Buenos Aires, Argentina and 2Department of Pharmacology, School of Medicine, University of Buenos Aires, Buenos Aires, Argentina

Received: 22 February 2010 Accepted: 5 May 2010 Published: 5 May 2010

\section{References}

1. Hedner U: Potential role of rFVIla in prophylaxis in severe haemophilia patients with inhibitors. J Thromb Haemost 2006, 4:2498-500

2. Hedner U: Mechanism of action, development and clinical experience of recombinant FVIla. J Biotechno/ 2006, 124:747-57.

3. Levi M, Peters M, Buller HR: Efficacy and safety of recombinant factor VIla for treatment of severe bleeding: a systematic review. Crit Care Med 2005, 33:883-90.

4. Romagnoli S, Bevilacqua S, Gelsomino S, Romagnoli S, Bevilacqua S, Gelsomino S, Pradella S, Ghilli L, Rostagno C, Gensini GF, Sorbara C: Smalldose recombinant activated factor VII (NovoSeven) in cardiac surgery. Anesth Analg 2006, 102:1320-6.

5. Stein DM, Dutton RP, Hess JR, Scalea TM: Low-dose recombinant factor VIla for trauma patients with coagulopathy. Injury 2008, 39:1054-61.

6. Altman R, Scazziota A, de Lourdes Herrera M, Gonzalez C: Recombinant factor Vlla reverses the inhibitory effect of aspirin or aspirin plus clopidogrel on in vitro thrombin generation. J Thromb Haemost 2006, 4:2022-7.

7. Hemker HC, Giesen P, Aldieri R, Regnault V, de Smed E, Wagenvoord R, Lecompte T, Beguin S: The calibrated automated thrombogram (CAT): a 
universal routine test for hyper- and hypocoagulability. Pathophysiol Haemost Thromb 2002, 32:249-53.

8. Abshire T, Kenet G: Safety update on the use of recombinant VIlla and the treatment of congenital and acquired deficiency of factor VIII or IX with inhibitors. Haemophilia 2008, 14:898-902.

9. Hedner U: Mechanism of action of factor VIla in the treatment of coagulopathies. Semin Thromb Hemost 2006, 32(Suppl 1):77-85.

10. Hedner U: Mechanism of action of recombinant activated factor VII: an update. Semin Hematol 2006, 43(1 Suppl 1):S105-7.

11. Wolberg AS, Allen GA, Monroe DM, Hedner U, Roberts HR, Hoffman M High dose factor VIla improves clot structure and stability in a model of haemophilia B. Br J Haematol 2005, 131:645-55.

12. Aggarwal A, Malkovska V, Catlett JP, Alcorn K: Recombinant activated factor VII ( $\mathrm{rFVIla}$ ) as salvage treatment for intractable hemorrhage. Thromb J 2004, 2:9.

13. Mayer SA, Brun NC, Begtrup K, Broderick J, Davis S, Diringer MN, Skolnick BE, Steiner T, Recombinant Activated Factor VII Intracerebral Hemorrhage Trial Investigators: Recombinant activated factor VII for acute intracerebral hemorrhage. N Engl J Med 2005, 352:777-85.

14. Bowman LJ, Uber WE, Stroud MR, Christiansen LR, Lazarchick J, Crumbley AJ, Kratz JM, Toole JM, Crawford FA Jr, Ikonomidis JS: Use of recombinant activated factor VII concentrate to control postoperative hemorrhage in complex cardiovascular surgery. Ann ThoracSurg 2008, 85:1669-76.

15. O'Connell KA, Wood JJ, Wise RP, Lozier JN, Braun MM: Thromboembolic adverse events after use of recombinant human coagulation factorVIIla. JAMA 2006, 295:293-8.

16. Pichon N, Bellec F, Sekkal S, Marsaud JP, Laskar M, François B, Vignon P: Fatal thrombotic event after infusion of recombinant activated factor VII after cardiac surgery. J Thorac Cardiovasc Surg 2008, 136:220-1.

17. Hsia CC, Chin-Yee IH, McAlister VC: Use of recombinant activated factor VII in patients without hemophilia: a meta-analysis of randomized control trials. Ann Surg 2008, 248:61-8.

18. Yilmaz D, Karapinar B, Balkan C, Akisü M, Kavakli K: Single-center experience: use of recombinant factor Vlla for acute life-threatening bleeding in children without congenital hemorrhagic disorder. Pediatr Hematol Oncol 2008, 25:301-11.

19. Alten JA, Benner K, Green K, Toole B, Tofil NM, Winkler MK: Pediatric offlabel use of recombinant factor Vlla. Pediatrics 2009, 123:1066-72.

20. Howes JL, Smith RS, Helmer SD, Taylor SM: Complications of recombinant activated human coagulation factor VII. Am J Surg 2009, 198:895-9.

21. Diringer MN, Skolnick BE, Mayer SA, Steiner T, Davis SM, Brun NC, Broderick $J \mathrm{~J}$ : Thromboembolic events with recombinant activated factor VII in spontaneous intracerebral hemorrhage: results from the Factor Seven for Acute Hemorrhagic Stroke (FAST) trial. Stroke 2010, 41:48-53.

22. Altman R, Scazziota AS, Herrera M de L, Gonzalez C: Thrombin generation by activated factor VII on platelet activated by different agonists. Extending the cell-based model of hemostasis. Thromb J 2006, 4:5.

23. Lisman T, Adelmeijer J, Cauwenberghs S, van Pampus ECM, Heemskerk JWM, de Groot PG: Recombinant factor Vlla enhances platelet adhesion and activation under flow conditions at normal and reduced platelet count. J Thromb Haemost 2005, 3:742-51.

24. Levi M, ten Cate H: Disseminated intravascularcoagulation. N Engl J Med 1999, 341:586-92

25. Morel O, Jesel L, Freyssinet JM, F Toti F: Elevated levels of procoagulant microparticles in a patient with myocardial infarction, antiphospholipid antibodies and multifocal cardiac thrombosis. Thromb J 2005, 3:15.

26. Franchini M, Giuseppe Lippi G, Manzato F: Recent acquisitions in the pathophysiology, diagnosis and treatment of disseminated intravascular coagulation. Thromb J 2006, 4:4.

27. Hedner U: Factor Vlla and its potential therapeutic use in bleedingassociated pathologies. Thromb Haemost 2008, 100:557-62.

28. Masud F, Bostan F, Chi E, Pass SE, Samir H, Stuebing K, Liebl MG: Recombinant factor Vlla treatment of severe bleeding in cardiac surgery patients: a retrospective analysis of dosing, efficacy, and safetyoutcomes. J Cardiothorac Vasc Anesth 2009, 23:28-33.

29. Friederich PW, Henny CP, Messelink EJ, Geerdink MG, Keller T, Kurth KH, Büller HR, Levi M: Effect of recombinant activated factor VII on perioperative blood loss in patients undergoing retropubic prostatectomy: a double-blind placebo-controlled randomised trial. Lancet 2003, 361:201-5.
30. Johnson SJ, Ross MB, Moores KG: Dosing factor Vlla (recombinant) in nonhemophiliac patients with bleeding after cardiac surgery. Am J Health Syst Pharm 2007, 64:1808-12.

31. Hsia CC, Chin-Yee IH, McAlister VC: Use of recombinant activated factor VII in patients without hemophilia: a meta-analysis of randomized control trials. Ann Surg 2008, 248:61-8.

32. Moreno PR, Purushothaman KR, Fuster V, Echeverri D, Truszczynska H, Sharma SK, Badimon JJ, O'Connor WN: Plaque neovascularization is increased in ruptured atherosclerotic lesions of human aorta: implications for plaque vulnerability. Circulation 2004, 110:2032-8.

doi: 10.1186/1477-9560-8-8

Cite this article as: Altman et al., The hemostatic profile of recombinant activated factor VII. Can low concentrations stop bleeding in off-label indications? Thrombosis Journal 2010, 8:8

\section{Submit your next manuscript to BioMed Central and take full advantage of:}

- Convenient online submission

- Thorough peer review

- No space constraints or color figure charges

- Immediate publication on acceptance

- Inclusion in PubMed, CAS, Scopus and Google Scholar

- Research which is freely available for redistribution
C) Biomed Central 